\title{
The Relevance of School Community Relationship on the Development of Primary Education in Azare Metropolis of Bauchi State, Nigeria
}

\author{
${ }^{1}$ Tata Umar Sa'ad, ${ }^{2}$ Abdullahi M. Sadiq \\ ${ }^{I}$ Senior Lecturer NCE, B. Ed \& M. Ed (Sociology of Education) Foundations Department School of Education \\ College of Education P. M. B. 044, Azare Bauchi State, Nigeria \\ ${ }^{2}$ Lecturer III B. A. (Ed) Geography PES Department School of Education College of Education P. M. B. 044 \\ Azare Bauchi State, Nigeria
}

\begin{abstract}
This study investigated the relevance of school community relationship on the development of primary education in Azare metropolis of Bauchi state, Nigeria. The population of the study comprises of headmasters and their assistants, teachers and SBMC members totaling to 2,752. The sample used was 388 selected using disproportionate stratified random sampling techniques. The data for the study was collected through structured questionnaire and were analyzed using frequency and simple percentage. It was found out that school community relationship is very relevant in the development of primary education in Azare metropolis due to the fact that community provides lands for building schools, funds, facilities, supervise what is going on in school, build additional classrooms and help in the maintenance of indiscipline. It was also found out that the school on the other hand, has resources which it uses to improve school community relationship and ultimately develops education which, include classrooms, play grounds, halls, surroundings, information dissemination to community and making itself available for consultations. The study recommended that good school community relationship should be maintained and strengthens; headmasters should try as much as possible to have more knowledge of the community by interacting with its members, LEA and SUBEB should encourage the primary schools to develop good school community relationship because of its positive contribution to education, workshops should be organized for members of the community and teachers on the importance of school community relationship, schools should take good care of their resources so that they can be use to strengthen school community relationship and schools should continue to enlighten community on the importance of school community relationship.
\end{abstract}

Key words: School, Community, Relationship, Primary Education.

\section{Introduction}

School as a social institution and agent of socialization needs to have a good relationship with immediate and far communities. Symbiotic relationship always exists between the school and the community which lead to the success of the two. Bakwai, (2013) was of the view that school community relationship is a two-way symbiotic arrangement through which the school and community cooperate with each other for realization of goals of the community and vice versa. Therefore, a school is a mini society that needs a good relation with the community for it to function effectively. On the other hand, the community also needs school for its survival and progress. Madumere, (2004) was of the view that school as a social system means that the school is part and parcel of the society. He added that the sociologist sees the school as belonging to the community that builds it.

Cordial relationship between the school and community is a pre-requisite for achieving a meaningful educational objective in our community and nation at large (Gital, 2009). Generally, community has a vital interest in what schools do and how they do it. The schools always reflect and promote community's values and interest. There is a vast of knowledge out there, more than any school can possibly hope to teach and so one of the tasks confronting school is to select what to teach. Each country chooses the curriculum to match and advance its view, history, values, interest and culture as a whole. Sadker, (2008) was of the view that community transmits its culture and view to the world.

It should be noted that community's values, ideas, norms and beliefs are to be perpetuated by the school being a social institution and at the same time, the pupils in the school come from the community (Aminu, 2006). Therefore, for successful development of education and primary one in particular depends so much on the relationship between the school and the community. Mitrofanova, (2014) and Bibire, (2014) were of the opinion that schools and communities should work closely with each other to meet their mutual goals of provision and management of education as well as teaching, learning and enforcement of processes. This is a kind of relationship in which both the school and the community contribute directly to the strengthening and 
development of each other, can provide a firm foundation for both educational renewal and community regeneration

Therefore, it is against this background that this study intends to investigate the relevance of school community relationship on the development of primary education in Azare metropolis of Bauchi state, Nigeria.

\section{Review of Related Literature}

The school and community are inseparable and their good relationship improves the quality of education given to the pupils. Mahuta, (2007) was of the view that school as a social institution is regarded as center of knowledge and it possesses the power to mould and shape the character of individuals in the community. For the school to perform its role effectively there is a need for good school community relationship. There are many areas in which school community relationship exist which aid in the development of education, particularly primary type.

The function of community towards maintaining and supporting its relationship with school and which ultimately lead to the development of education cannot be overemphasized. It is a known fact that there can never be a school where there is no community. The communities normally provide lands in which the schools are build as well as providing children enrolment. Nasiru, (2008) and Gital, (2009) were of the view that community provides school with the land to be established, fund it, provide facilities to it and help greatly in the improvement of the performance of pupils and general development of education. Generally, the school utilizes the community resources for teaching and learning purposes and at the same time derives its curriculum from the community (Mahuta, 2007). Agbaje, (1990), Adeboyeje, (1994) and Cohen, (1998) in Ogundele, Oparinde and Oyewale, (2012) were of the opinion that school community relationship have significant impact on the provision and maintenance of school facilities, school discipline, teachers job performance, academic achievement of students and overall success of the schools. This clearly shows that school community relationship exists and helps greatly in the development of education.

In another vein, community maintains its relationship with school by providing resource mobilization. This is mostly done through the School Based Management Committees and Parent Teachers Associations. When there is any urgent need by the school, the community mobilizes resources from its members. It is through this kind of relationship that community members donate a lot of materials to their immediate school, like furniture, teaching materials including note and textbooks, chalk etc. Sa'ad and Nasiru, (2009) were of the view that community donates many resources to their immediate schools, particularly primary ones. In addition to that Adeboyeje, (1994) in Ogundele, Oparinde and Oyewale, (2012) was categorically of the view that community members have significant impact on the provision and maintenance of school facilities through PTA and other community based organizations. This also clearly indicates that there is school community relationship and it assists a lot in the development of education, particularly primary one.

The school has a lot of resources which it uses to develop, maintain and strengthen school community relationship in addition to its main role of imparting knowledge and socialization of the younger generation. Bibire, (2014) was of the view that the impact of the schools on the community will largely depends on bonds as well as on how the school systems are organized and degree to which they are organically integrated with the community needs and aspirations.

One of the important resources of the school which aid in strengthening school community relationship and improves education is allowing community to use school facilities. Mostly, in northern Nigeria, it is common to all that the primary school buildings or classes are used by "Islamiyya" in the evening or in the night. In relation to that Mitrofanova, (2011) was of the view that encouraging non-profit community groups to use the facilities is not only good use of resources but also provide opportunities for the schools to get involved in community projects. In addition to that community members make use of the school compound for parking their valuables, particularly cars in the night for security reasons. School halls and play grounds are used by the community for meetings, conduct of cultural festivities and games. Nasiru, (2008) and Bakwai, (2013) were of the view that school halls are used for community meetings, play grounds for games and cultural activities; and the school building for emergency cases.

The school also assists the community in sharing good information with the public. A lot of messages reach the community through the schools, particularly in our villages. Pawlas, (2005), Mitrofanova, (2011) and Bakwai, (2013) were of the view that school pass vital information to the community and it is normally done through news release and newsletters. This sharing of information creates better school community relationship which ultimately improves teaching and learning and general development of education, particularly primary one.

Mahuta, (2007) was of the opinion that the school community relationship has long been recognized as a strong tie for the smooth running of the school in the community. He identifies the role of the school as a community center: 
> The school is a community learning center, a place that serves as a custodian of the traditional values of the community.

> The school should endeavour to establish social organizations and allow members of the community to actively participate in improving and sponsoring the organizations in the school.

> The school should allow for existence of social clubs that are attractive and creative to the students, parents and community members.

$>$ The school remains a place where the members of the community consult for issues and problems to be solved or addressed.

Therefore, school community relationship is very necessary for the survival, continuity and progress of both the school and the community. It is also necessary for the development of education, particularly primary one which this paper capitalized on. It is pertinent for both the school and community to maintain and strengthen their relationship for the betterment of themselves and development of education.

\section{Objectives of the Study}

This study intends to achieve the following objectives:

1. To identify the contributions of community towards its relationship with the school which help in the development of primary education in Azare metropolis of Bauchi state.

2. To identify the school resources that can be used to support its relationship with the community and the development of primary education in Azare metropolis of Bauchi state.

\section{Research Design}

The design adopted and used in this study was a descriptive survey. It was used because it permitted the researcher to study small sample and later generalized the findings to the whole population. Osuala, (2005) was of the view that in survey research small sample is studied and the findings generalized to the population.

\section{Research Questions}

This study aims at answering the following research questions:

1. What are the contributions of community towards its relationship with the school which help in the development of primary education in Azare metropolis of Bauchi state?

2. What are the school resources that can be used to support its relationship with the community and the development of primary education in Azare metropolis of Bauchi state?

\section{Population of the Study}

The population of this study was two thousand, seven hundred and fifty-two $(2,752)$. The population comprises of headmasters, assistant headmasters, teachers and School Based Management Committee (SBMC) members.

\begin{tabular}{lll} 
& \multicolumn{2}{c}{ The table below shows the distribution of the population. } \\
\hline S/NO. & CATEGORY & POPULATION \\
\hline 1. & HEADMASTERS & 37 \\
2. & ASSISTANT HEADMASTERS & 37 \\
3. & TEACHERS & 2,049 \\
4. & SBMC MEMBERS & 629 \\
TOTAL & & $\mathbf{2 , 7 5 2}$ \\
\hline
\end{tabular}

\section{Source: Fieldwork, 2014}

Sample for the Study

The sample for this study was three hundred and eighty-eight. The sample was chosen based on Krejcie and Morgan's (1984) table for determining sample as contained in Kolo, (1992).

The table below shows the distribution of the sample.

\begin{tabular}{lll}
\hline S/NO. & CATEGORY & SAMPLE \\
\hline 1. & HEADMASTERS & 37 \\
2. & ASSISTANT HEADMASTERS & 37 \\
3. & TEACHERS & 222 \\
4. & SBMC MEMBERS & 92 \\
TOTAL & & $\mathbf{3 8 8}$ \\
\hline
\end{tabular}

Source: Fieldwork, 2014 


\section{Sampling Technique}

The sampling technique used in selecting the sample for this study was disproportionate stratified random sampling technique. It was used because it allows for taking representative from each category of the population. In other words, the sampling techniques allows for taking sample from headmasters, assistant headmasters, teachers and SBMC members.

\section{Instrument for Data Collection}

The instrument used in the collection of data for this study was a structured questionnaire design by the researcher. The questionnaire comprises of twelve structured questions on the relevance of school community relationship on the development of primary education in Azare metropolis of Bauchi state.

\section{Validity and Reliability of the Instrument}

The instrument was validated by experts who have more than two decades of teaching research methods in College of Education, Azare. Based on their advices some questions were modified, some dropped and others added in order to make the instrument valid.

The reliability of the instrument was determined by using test-retest method. The instrument was used on fifty members of the population and after ten days the same instrument was used again on same people. The two results were correlated using Pearson Product Moment correlation coefficient and the result got was 0.8. This makes the instrument reliable.

\section{Data Analysis Procedure}

The data collected from the questionnaire was a discrete one and frequency and simple percentage were used in its analysis.

\section{Data Presentation, Analysis and Discussion of Results}

This section focuses on presentation and analysis of the data collected from the respondents as well as the discussion of the results.

Research Question1: What are the contributions of community towards its relationship with the school which help in the development of primary education in Azare metropolis of Bauchi State?

Table 3: Showing responses obtained from research question one.

\begin{tabular}{|c|c|c|c|}
\hline \multirow{2}{*}{ S/No. } & \multirow{2}{*}{ Question } & \multicolumn{2}{|c|}{ Response } \\
\hline & & Yes $\%$ & NO $\%$ \\
\hline 1. & $\begin{array}{l}\text { Does your community provide lands for building of primary } \\
\text { schools? }\end{array}$ & $247(64 \%)$ & $141(36 \%)$ \\
\hline 2. & $\begin{array}{l}\text { Does your community provide facilities like furniture, books } \\
\text { and other materials to primary school? }\end{array}$ & $235(61 \%)$ & $153(39 \%)$ \\
\hline 3. & Does your community helps in funding the primary schools? & $197(51 \%)$ & $191(49 \%)$ \\
\hline 4. & $\begin{array}{l}\text { Does your community helps in maintenance of discipline in } \\
\text { primary schools? }\end{array}$ & $346(89 \%)$ & $42(11 \%)$ \\
\hline 5. & $\begin{array}{l}\text { Does your community supervise what the teachers are doing } \\
\text { in the primary schools? }\end{array}$ & $199(51 \%)$ & $189(49 \%)$ \\
\hline 6. & $\begin{array}{l}\text { Does your community helps in provision of more } \\
\text { classrooms in the primary schools? }\end{array}$ & $228(59 \%)$ & $160(41 \%)$ \\
\hline
\end{tabular}

Source: Fieldwork, 2014.

In table 3 above, 247 respondents representing $64 \%$ were of the view that community provides lands for the building of primary schools in Azare metropolis while 141 respondents representing 36\% were against this view. On the other hand, 235 respondents representing $61 \%$ were of the view that community provides facilities like furniture, books and other materials to the primary schools while 153 respondents representing $39 \%$ were not in support of that view. 197 respondents representing $51 \%$ were of the opinion that community helps in funding primary schools in Azare metropolis while 191 representing 49\% were against this opinion. 346 respondents representing $89 \%$ were of the view that community helps a lot in maintaining discipline in primary schools of Azare metropolis while 42 respondents representing only $11 \%$ were against this view. 199 respondents representing 51\% were of the view that community visits and supervise what the teachers are doing in the primary schools of Azare metropolis while 189 respondents representing $49 \%$ were against this view. Finally, 228 respondents representing $59 \%$ were of the opinion that community helps in providing additional classrooms in primary schools of Azare metropolis while 160 respondents representing $41 \%$ were against this opinion.

Therefore, it is clear to us that there is a good school community relationship in primary schools of Azare metropolis because of the areas that community contributes to the schools and which ultimately leads to the development of primary education in the study area. As it is evidently seen in the above table, the 
community provides lands, facilities, fund, maintenance of discipline, supervise the teachers and even provision of classrooms in some cases.

Research Question 2: What are the school resources that can used to support its relationship with the community and the development of primary education in Azare metropolis of Bauchi State?

Table 4: Showing responses on research question two.

\begin{tabular}{|c|c|c|c|}
\hline \multirow[t]{2}{*}{ S/No. } & \multirow[t]{2}{*}{ Question } & \multicolumn{2}{|c|}{ Response } \\
\hline & & Yes \% & NO \% \\
\hline 1. & $\begin{array}{l}\text { Do the primary schools in Azare metropolis allow the } \\
\text { community to make use of their classrooms when they } \\
\text { closed for the day or on holidays? }\end{array}$ & $388(100 \%)$ & $00(00 \%)$ \\
\hline 2. & $\begin{array}{l}\text { Do the primary schools in Azare metropolis allow the } \\
\text { community to make use of their compound for parking or } \\
\text { keeping their valuables particularly, vehicles like cars for } \\
\text { security? }\end{array}$ & $368(95 \%)$ & $20(5 \%)$ \\
\hline 3. & $\begin{array}{l}\text { Do the primary schools in Azare metropolis allow the } \\
\text { community to make use of their play grounds for games and } \\
\text { cultural activities? }\end{array}$ & $388(100 \%)$ & $00(00 \%$ \\
\hline 4. & $\begin{array}{l}\text { Do the primary schools in Azare metropolis allow the } \\
\text { community to make use of their surroundings for social } \\
\text { meetings and other emergencies like natural disaster? }\end{array}$ & $379(97 \%)$ & $9(3 \%)$ \\
\hline 5. & $\begin{array}{l}\text { Do the primary schools in Azare metropolis allow the } \\
\text { community to consult them on any issues that needs } \\
\text { clarification and solution? }\end{array}$ & $345(89 \%)$ & $43(11 \%)$ \\
\hline 6. & $\begin{array}{l}\text { Do the primary schools of Azare metropolis share or pass } \\
\text { important information to the community like enlighten on } \\
\text { diseases like Ebola. }\end{array}$ & $203(52 \%)$ & $185(48 \%)$ \\
\hline
\end{tabular}

In table 4 above, it is clearly evident that all the respondents were of the view that primary schools in Azare metropolis allow the community to make use of their classes for other programmes like "Islamiyya" schools, particularly in the evening and nights. On the other hand, 368 respondents representing $95 \%$ were of the opinion that the primary schools in Azare allow the community to make their compound for parking their vehicles, particularly cars in the night for security, while 20 respondents representing $5 \%$ were against this opinion. Again, all the respondents were of the view that the primary schools in Azare metropolis allow the community to make use of their play grounds for games (football) and other cultural activities. 379 respondents representing $97 \%$ were of the opinion that primary schools in Azare metropolis normally allow the community to make use of their surroundings for social meetings as well as when there is any emergency particularly that natural disaster or any disturbances that displaces people, while respondents representing $3 \%$ were against the opinion. About 345 respondents representing $89 \%$ were of the view that primary schools in Azare metropolis allow the community to consult them on any issue that requires clarification and solution, while 43 representing $11 \%$ were against this view. Finally, 203 respondents representing $52 \%$ were of the opinion that primary schools in Azare metropolis provide the community with a lot of information that enlighten individuals on issues like modes of spread of diseases and their control, while 185 representing $48 \%$ were against this opinion.

Therefore, it is evidently clear that primary schools in Azare metropolis are having a lot of resources that encourage school community relationship and which lead to development of primary education in the study area. The primary schools in Azare metropolis allow the community to make use of their resources like the classrooms, play grounds and surroundings. They also provide or pass information to the community on some societal issues as well as making themselves available for consultation when any arises.

\section{Discussion of Results}

The discussion of results was done based on the research questions raised in the study.

\section{Research Question One}

The results of the analysis of research question one showed that school community relationship is relevant in the development of primary education in Azare metropolis because it leads to the provision of land, facilities, discipline, supervision, classrooms, as well as information funds to primary schools in Azare metropolis, which ultimately leads to development education. This tallies with the findings of Nasiru, (2008), Gital, (2009), Mahuta, (2007), Sa'ad and Nasiru, (2009) Agbaje, (1990), Adeboyeje, (1994), and Cohen, (1998) in Ogundele, Oparinde and Oyewale, (2012) who were of opinion that community provides land, children as well as provision and maintenance of school facilities, school discipline teachers job performance, academic achievement of students and overall success of the school. 


\section{Research Question Two}

The result of the analysis of research question two showed that school resources like classrooms, compounds, halls and play grounds are always used by the community for one activity or the other. In addition to that community benefited from the primary school by getting information and clarifications on some issues that affect the people around. This ultimately encourages school community relationship and general development of primary education in Azare metropolis. This tallies with the findings of Pawlas, (2005), Mahuta, (2007), Nasiru, (2009), Mitrofanova, (2011), Bakwai, (2013) and Bibire, (2014) who were of the opinion that the school resources like the classrooms, play grounds, halls, surroundings, compounds as well as provision of information through news release and news letter are used by community which improves its relationship with the school and ultimately develops education..

\section{Conclusion}

Based on the findings of this study, the following conclusions were made:

That school community relationship is very relevant in the development of primary education in Azare metropolis of Bauchi state. This is clearly evident due to the fact that the community provides many things to the school such as land for building schools, funds, facilities, supervisions, discipline and classrooms. This helps greatly in sustaining and strengthening school community relationship which ultimately leads to the development of primary education in Azare metropolis.

That the primary schools in Azare metropolis have a lot of resources which encourage school community relationship and assist in the development of education. Primary school resources like classrooms, play grounds, halls, school compound, giving necessary consultations and clarifications as well as information provision to community are always available to the people around. This helps greatly in maintaining and strengthening school community relationship in primary schools of Azare metropolis.

\section{Recommendations}

The following recommendations were forwarded:

Good school community relationship should be maintained and strengthen for the purpose of improving the academic achievement of pupils as well as the general development of primary education in Azare metropolis of Bauchi state.

The headmasters and their assistants should try as much as possible to have the knowledge of the immediate community so as to relate with well them

Local Education Authority (LEA) and State Universal Basic Education Board (SUBEB) should encourage the primary schools to develop good school community relationship for betterment of primary education.

The primary schools should take good care of their resources so that they can be used to strengthen the school community relationship in Azare metropolis.

The headmasters should enlighten the community on the importance of their involvement in the affairs of the primary schools.

Workshops should be organized by both SUBEB and LEAs for both community members and the teachers on the importance of school community relationship.

\section{References}

[1]. Aminu, J. (2006). Quality \& Stress in Nigerian Education. Zaria: University Press

[2]. Bakwai, B. (2013). Assessment of School Community Relationship in Secondary School in Zamfara State. Retrieved 23rd September, 2014 from http://www.acdemia.edu/3999314/

[3]. Bibire, A. (2014). Community Participation in Education: Challenges and Prospects in Nigeria. Retrieved $23^{\text {rd }}$ September, 2014 from http://challengenigeria.com.ngcommunity-participation-in-education challenges-and- prospects-in-nigeria/

[4]. Gital, M. A. (2009). The Impact of School-Community Relationship on Primary Education (A Case Study of Some Selected Communities of Tafawa Balewa Local Government Area of Bauchi State). Unpublished PGDE Project. College of Education, Azare, Affiliated to the University of Maiduguri, Nigeria.

[5]. Kolo, A. I. (1992). Essential of Research in Education (A Handbook for Students and Beginning Researchers in Education). Lagos: Text and Leisure Publishers.

[6]. Mahuta, M. G. (2007). An Introduction to Socilogical Foundation of Education. Calabar: But-Bass Educational Books (BEB).

[7]. Mitrofanova, Y. (2011). Building Community-School Relations.Retrieved 23 ${ }^{\text {rd }}$ September, 2014 from http://lancaster.unl.edu/community/articles/communityschools.shtml

[8]. Madumere, S. C. (2004). Social \& Philosophical Aspects of Educational Planning. Lagos: Vita Nasco Publishing Co.

[9]. Nasiru, M. A. (2008). The Impact of School-Community Relationship on Primary Education In Azare Metropolis. Unpublished PGDE Project. College of Education, Azare affiliated to the University of Maiduguri.

[10]. Ogundele, M. O., Oparinde, F. O. \& Oyewale, M. K. (2012). Community-School Relations and Pricipals Administrative Effectiveness of Secondary Schools in Kwara State.

Retrieved from http://www.mcser.org/images/studies/JESRJOURNAL/jesrseptember2012 school\%20relation.pdf

[11]. Osuala, E. O. (2005). Introduction to Research Methodology.(Rev. Ed) Onitsha: African Fab Publishers. 
[12]. Pawlas, G. E. (2005). The administration guide to school community relation ( $2^{\text {nd }}$ ed.). Library of Cataloging in Publication. Retrieved $23^{\text {rd }}$ August, 2014 from http://books.google.ca/book?id

[13]. Sa'ad, T. U. (2007). The Impact of Domestic Responsibilities on the Academic achievement of Married Women in Tertiary Institutions of Bauchi state. Unpublished M.Ed Thesis. Bayero University, Kano.

[14]. Sa'ad, T. U. and Nasiru, A. M. (2010). "The Significance Of School-Community Relationship on Education". In Azare Journal of Education: 8(1)

[15]. Sadker, M. P. (2005). Teachers, Schools and Society (7the ed). Boston: McGraw Hill. 